\title{
Predicting timothy mineral concentrations, dietary cation-anion difference, and grass tetany index by near-infrared reflectance spectroscopy
}

\author{
G. F. Tremblay, ${ }^{* 1}$ Z. Nie, $†$ G. Bélanger, ${ }^{*}$ S. Pelletier, ${ }^{*}$ and G. Allardł \\ *Agriculture and Agri-Food Canada, Soils and Crops Research and Development Centre, Québec, Québec, Canada G1V 2J3 \\ †Department of Grassland Science, College of Animal Science and Technology, China Agricultural University, Beijing, P. R. China, 100094 \\ ‡Université Laval, Québec, Québec, Canada G1K 7P4
}

\section{ABSTRACT}

The mineral concentration of forage grasses plays a significant role in 2 metabolic disorders in dairy cattle production, namely, hypocalcemia (milk fever) and hypomagnesemia (grass tetany). Risks of occurrence of these 2 metabolic disorders can be evaluated by determining the dietary cation-anion difference (DCAD) and the grass tetany (GT) index of forages and specific rations. The objective of this study was to evaluate the feasibility of predicting timothy (Phleum pratense L.) mineral concentrations of $\mathrm{Na}, \mathrm{K}, \mathrm{Ca}, \mathrm{Mg}, \mathrm{Cl}, \mathrm{S}$, and $\mathrm{P}$, the DCAD, and the GT index by near-infrared reflectance spectroscopy (NIRS). Timothy samples ( $\mathrm{n}=$ 1,108) were scanned using NIRS and analyzed for the concentration of 7 mineral elements. Calculations of the DCAD were made using 3 different formulas, and the GT index was also calculated. Samples were divided into calibration $(\mathrm{n}=240)$ and validation $(\mathrm{n}=868)$ sets. The calibration, cross-validation, and prediction for mineral concentrations, the DCAD, and the GT index were performed using modified partial least squares regression. Concentrations of $\mathrm{K}, \mathrm{Ca}, \mathrm{Mg}, \mathrm{Cl}$, and $\mathrm{P}$ were successfully predicted with coefficients of determination of prediction $\left(\mathrm{R}_{\mathrm{P}}^{2}\right)$ of 0.69 to 0.92 and coefficients of variation of prediction $\left(\mathrm{CV}_{\mathrm{P}}\right)$ ranging from 6.6 to $11.4 \%$. The prediction of $\mathrm{Na}$ and $\mathrm{S}$ concentrations failed, with respective $\mathrm{R}_{\mathrm{P}}^{2}$ of 0.58 and 0.53 and $\mathrm{CV}_{\mathrm{P}}$ of 82.2 and $12.9 \%$. The 3 calculated DCAD and the GT index were predicted successfully, with $\mathrm{R}_{\mathrm{P}}^{2}$ $>0.90$ and $\mathrm{CV}_{\mathrm{P}}<20 \%$. Our results confirm the feasibility of using NIRS to predict $\mathrm{K}, \mathrm{Ca}, \mathrm{Mg}$, and $\mathrm{Cl}$ concentrations, as well as the DCAD and the GT index, in timothy.

Key words: Phleum pratense, milk fever, hypomagnesemia, near-infrared reflectance spectroscopy

Received December 12, 2008.

Accepted May 6, 2009.

${ }^{1}$ Corresponding author: tremblaygf@agr.gc.ca

\section{INTRODUCTION}

Hypocalcemia (milk fever) and hypomagnesemia (grass tetany) are 2 important metabolic disorders in dairy cattle production. These disorders usually occur when the supplies of $\mathrm{Ca}$ and $\mathrm{Mg}$ are inadequate during early lactation (Jefferson et al., 2001). The risk of milk fever and grass tetany occurring can be evaluated by determining the DCAD and the grass tetany $(\mathbf{G T})$ index of forages and specific rations. Three formulas are commonly used to calculate the DCAD in dairy cattle rations (Pelletier et al., 2008):

$$
\mathrm{DCAD} 1=(\mathrm{Na}+\mathrm{K})-(\mathrm{Cl}+\mathrm{S})
$$

(Ender et al., 1971);

$$
\begin{aligned}
\text { DCAD2 }= & (\mathrm{Na}+\mathrm{K}+0.15 \mathrm{Ca}+0.15 \mathrm{Mg}) \\
& -(\mathrm{Cl}+0.6 \mathrm{~S}+0.5 \mathrm{P})
\end{aligned}
$$

(NRC, 2001); and

$$
\mathrm{DCAD} 3=(\mathrm{Na}+\mathrm{K})-(\mathrm{Cl}+0.6 \mathrm{~S})
$$

(Goff et al., 2004), where DCAD is expressed in millimoles of charge $\left(\mathbf{m m o l}_{\mathbf{c}}\right) / \mathrm{kg}$ of DM $(\mathrm{g} / \mathrm{kg}$ of DM $\times$ $1,000 \times$ valence/atomic weight). The GT index is calculated using the following formula:

$$
\mathrm{GT} \text { index }=\mathrm{K} /(\mathrm{Ca}+\mathrm{Mg})
$$

(Kemp and 't Hart, 1957).

The DCAD1 formula is widely used in applied dairy cattle nutrition because it is well correlated with urinary $\mathrm{pH}$ and is predictive of clinical milk fever. DeGaris and Lean (2008) suggested that DCAD1 was the most effective formula for predicting the risk of milk fever, based on the simplified strong ion model and the metaanalysis of Lean et al. (2006). However, Charbonneau et al. (2006) reported that DCAD3 was most highly associated with milk fever $\left(\mathrm{R}^{2}=0.44\right)$ and urinary $\mathrm{pH}$ 
$\left(\mathrm{R}^{2}=0.85\right)$ according to their meta-analysis of 22 published studies.

To prevent milk fever, dairy cows should be fed a ration with a DCAD1, DCAD2, and DCAD3 of approximately $-50,150$, and $-42 \mathrm{mmol}_{\mathrm{c}} / \mathrm{kg}$ of $\mathrm{DM}$, respectively, beginning from 3 to 4 wk before calving (Goff and Horst, 2003; Pelletier et al., 2008). The respective DCAD1 and DCAD3 values of forages should be no more than 250 and $290 \mathrm{mmol}_{\mathrm{c}} / \mathrm{kg}$ of DM to avoid adding excessive amounts of anionic salts, such as those based on $\mathrm{CaCl}_{2}$ or $\mathrm{MgCl}_{2}$, which reduce DMI (Horst et al., 1997; Pelletier et al., 2008). The occurrence of grass tetany is greatly increased for cattle grazing forages with a GT index higher than 2.2 (Jefferson et al., 2001).

Timothy (Phleum pratense L.) is the dominant perennial forage grass species grown in eastern Canada (Bélanger et al., 2001). Several studies have reported lower values of $\mathrm{K}$ concentration, the $\mathrm{DCAD}$, or the GT index for timothy compared with other forage grasses such as orchardgrass (Dactylis glomerata L.) or phalaris (Phalaris aquatica L.; Thomas et al., 1998; Tremblay et al., 2006; Pelletier et al., 2008). Timothy is therefore a forage species well suited to decrease risks of milk fever and grass tetany. Data on the DCAD and the GT index of timothy and other forage species are commonly obtained after chemical determinations of several minerals, rendering the acquisition of these indices time-consuming and expensive.

Near-infrared reflectance spectroscopy (NIRS) has been widely used as a fast and cost-effective method for determining forage nutritive value (Shenk and Westerhaus, 1994). The ability of NIRS to predict forage nutritive value and many other organic substances is based on the rotational or vibrational energies of hydrogen bonds. Although minerals theoretically do not absorb energy in the near-infrared spectrum, some of the inorganic minerals in forages can be predicted by NIRS (Clark et al., 1987, 1989; Halgerson et al., 2004) through their association with organic molecules. The NIRS prediction of minerals has produced many inconsistent results in forage analyses. Clark et al. (1987) reported that NIRS calibrations for the macrominerals $\mathrm{Ca}, \mathrm{P}, \mathrm{Mg}$, and $\mathrm{K}$ were useful in crested wheatgrass [Agropyron cristatum (L.) Gaertn.] and alfalfa (Medicago sativa L.). Halgerson et al. (2004) obtained similar results, in which concentrations of $\mathrm{Ca}, \mathrm{P}$, and $\mathrm{K}$ were accurately predicted in leaves and stems of alfalfa hay, whereas predictions of $\mathrm{Mg}$ and $\mathrm{S}$ were less consistent and prediction of Na failed. In contrast, Stoltz (1990) reported that calibrations for $\mathrm{Ca}, \mathrm{K}, \mathrm{P}$, and $\mathrm{Mg}$ in alfalfa and white clover (Trifolium angustifolium L.) were unsuccessful, and in other studies, difficulties were also found in obtaining accurate NIRS predictions for miner- als (Redshaw et al., 1986; Saiga et al., 1989). Based on reported successful NIRS predictions for some minerals needed in calculation of the DCAD and the GT index, we hypothesized that predicting the DCAD and the GT index is possible. To our knowledge, information on the possibility of predicting the DCAD and the GT index of timothy with NIRS is limited. The objective of this study was to evaluate the feasibility of using NIRS to predict $\mathrm{Na}, \mathrm{K}, \mathrm{Ca}, \mathrm{Mg}, \mathrm{Cl}, \mathrm{S}$, and $\mathrm{P}$ concentrations, as well as the DCAD and the GT index in timothy.

\section{MATERIALS AND METHODS}

\section{Samples}

This study was part of a larger experiment described in detail by Pelletier et al. (2007) in which we determined the influence of $\mathrm{Cl}$ and $\mathrm{N}$ fertilizer applications on DCAD. Timothy (P. pratense L., cv. Champ) samples $(\mathrm{n}=1,108)$ were collected in 2003 and 2004 at 4 locations in the province of Québec, Canada, as described by Pelletier et al. (2007). Timothy was sown in 2002 at Sainte-Anne-de-Bellevue $\left(45^{\circ} 24^{\prime} \mathrm{N}, 73^{\circ} 57^{\prime} \mathrm{W}\right)$, Normandin $\left(48^{\circ} 51^{\prime} \mathrm{N}, 72^{\circ} 32^{\prime} \mathrm{W}\right)$, and Saint-Augustin-deDesmaures $\left(46^{\circ} 44^{\prime} \mathrm{N}, 71^{\circ} 27^{\prime} \mathrm{W}\right)$, and in 1998 at SaintePerpétue $\left(46^{\circ} 05^{\prime} \mathrm{N}, 72^{\circ} 28^{\prime} \mathrm{W}\right)$. Ten fertilizer treatments (seasonal applications of $0,80,160$, and $240 \mathrm{~kg}$ of $\mathrm{Cl} /$ ha as $\mathrm{CaCl}_{2}, 160 \mathrm{~kg}$ of $\mathrm{Cl} / \mathrm{ha}$ as $\mathrm{NH}_{4} \mathrm{Cl}$, all combined with $\mathrm{N}$ fertilization that provided 70 or $140 \mathrm{~kg}$ of $\mathrm{N} / \mathrm{ha}$ as $\mathrm{NH}_{4} \mathrm{NO}_{3}$ for $\mathrm{CaCl}_{2}$ treatments or a mix of $\mathrm{NH}_{4} \mathrm{NO}_{3}$ and $\mathrm{NH}_{4} \mathrm{Cl}$ for $\mathrm{NH}_{4} \mathrm{Cl}$ treatments) were applied in a split application: $60 \%$ before the start of spring growth and $40 \%$ after the first harvest. Individual plot size was $6 \times 1.5 \mathrm{~m}$. In Sainte-Anne-de-Bellevue, Normandin, and Saint-Augustin-de-Desmaures, half of the timothy plots were harvested to a 5 -cm height when timothy reached the late-heading stage, and the other half were harvested $7 \mathrm{~d}$ later in both spring growth and summer regrowth. In Sainte-Perpétue, timothy was harvested at the late-heading stage only. Plots were harvested with a self-propelled flail forage harvester (Carter MGF Co. Inc., Brookston, IN) at Normandin and Sainte-Perpétue and with a REM flail forage harvester (Swift Machine and Welding, Swift Current, Saskatchewan, Canada) at Sainte-Anne-de-Bellevue and Saint-Augustin-deDesmaures.

A sample of approximately $500 \mathrm{~g}$ was taken from each plot, weighed, dried at $55^{\circ} \mathrm{C}$ in a forced-draft oven for 3 $\mathrm{d}$, and then ground using a Wiley mill (Standard model 3, Arthur H. Thomas Co., Philadelphia, PA) to pass through a 1-mm screen. All dried and ground timothy samples $(\mathrm{n}=1,108)$ were stored in plastic containers at room temperature in a dark room. Samples were scanned between July 7 and 19, 2006, at 2-nm intervals 
from 400 to 2,498 nm using a Foss NIRSystems 6500 monochromator (Foss, Silver Spring, MD) and spinning (ring) cups. Instrument performance was checked daily by running a performance test and analyzing the check cell. For each spectrum, principal components analysis scores were calculated by the $\mathrm{H}$ distance using the SCORES program of WinISI III software (version 1.61, Infrasoft International LLC, Silver Spring, MD). Based on the SELECT algorithm of the WinISI software, 240 timothy samples were then selected to form a calibration set, and the remaining 868 samples formed the validation set.

\section{Chemical Analyses and NIRS Calibration}

All timothy samples were analyzed for $\mathrm{Na}, \mathrm{K}, \mathrm{Ca}$, $\mathrm{Mg}, \mathrm{Cl}, \mathrm{S}$, and $\mathrm{P}$ concentrations as described by Pelletier et al. (2007, 2008). In brief, S was extracted by a method adapted from Mills and Jones (1996). Sodium and Ca were extracted by dry ashing (Miller, 1998) and $\mathrm{K}, \mathrm{Mg}$, and $\mathrm{P}$ were extracted using a method adapted from Isaac and Johnson (1976) and then analyzed with a Perkin-Elmer 3300 atomic absorption spectrometer (Perkin-Elmer, Überlingen, Germany) by flame emission for $\mathrm{K}$ and atomic absorption for $\mathrm{Ca}, \mathrm{Mg}$, and $\mathrm{Na}$. Phosphorus and $\mathrm{S}$ were analyzed using an automated continuous-flow injection analyzer (QuikChem 8000 Lachat autoanalyzer, Zellweger Analytics Inc., Lachat Instruments, Milwaukee, WI). Chloride was extracted using a method adapted from Liu (1998) and measured with a Dionex DX 500 chromatograph equipped with an ASII HC column (Dionex Corporation, Sunnyvale, CA). For each mineral, 66 samples were randomly selected and analyzed in duplicate to determine the standard error of laboratory (SEL). The DCAD1, DCAD2, and DCAD3 were calculated with 3 different formulas (equations [1], [2], and [3]) and the GT index was calculated with equation [4], with each mineral expressed in millimoles of charge per kilogram of DM $(\mathrm{g} / \mathrm{kg}$ of DM $\times 1,000 \times$ valence/atomic weight; $1 \mathrm{mmol}_{\mathrm{c}} / \mathrm{kg}$ of $\mathrm{DM}$ $=1 \mathrm{mEq} / \mathrm{kg}$ of $\mathrm{DM})$.

The regression method chosen to develop calibration equations for the DCAD, the GT index, and all related minerals was modified partial least squares (Shenk and Westerhaus, 1991). A repeatability file (n $=85$ ) was created by collecting, during the scanning time, 5 spectra per sample using independently filled cups for 17 randomly selected samples, and this file was applied in every calibration process to account for possible operator errors (Nie et al., 2009a). To improve the calibration models, 20 spectral pretreatments were tested (WinISI III software, version 1.61, Infrasoft International LLC). The correction of the scatter effect was done using standard normal variate and detrending mathematical procedures were applied (Barnes et al., 1989). Several derivative pretreatments were evaluated: the derivatives used a 4-digit notation, in which the first digit was the number of the derivative, the second was the gap over which the derivative was calculated, the third was the number of data points in a running average or smoothing, and the fourth was the second smoothing. Two criteria were used to select the best spectral pretreatment parameters: simultaneous low standard errors (SECV) and high coefficient of determination $(\mathbf{1}-\mathbf{V R})$ in cross-validation (Table 1). The best spectral pretreatment parameters were $(1,4,4,1)$ for $\mathrm{Ca}$ and $\mathrm{Cl},(1,10,10,1)$ for DCAD1, DCAD2, DCAD3, and the GT index, and $(2,5,5,2)$ for $\mathrm{Na}, \mathrm{K}$, $\mathrm{Mg}, \mathrm{S}$, and $\mathrm{P}$. When developing the NIRS equations, 4 cross-validation groups were selected to choose the optimal number of terms and avoid overfitting (Shenk and Westerhaus, 1994).

\section{Statistics}

The accuracy of chemical analyses was quantified by the SEL, which is the standard error of duplicates analyzed by the reference method, calculated with the following equation (Urbano-Cuadrado et al., 2004):

$$
\mathrm{SEL}=\sqrt{\frac{1}{\mathrm{n}} \sum_{i}\left(\mathrm{x}_{1}-\mathrm{x}_{2}\right)^{2}},
$$

where $\left(\mathrm{x}_{1}-\mathrm{x}_{2}\right)$ is the difference between duplicate measurements by the reference method on sample $i$, and $\mathrm{n}$ is the number of samples analyzed in duplicate. Coefficients of variation of the reference methods $\left(\mathbf{C V}_{\mathbf{R}}\right)$ between duplicate analyses were also calculated as follows:

$$
\mathrm{CV}_{\mathrm{R}}=[(\mathrm{SEL} / \mathrm{mean}) \times 100] .
$$

The calibration monitoring procedure implemented in the WinISI III software (version 1.61, Infrasoft International LLC) was used for validation of the equations. This procedure calculates 2 control limits: the bias control limits (BCL $\leq 0.6$ SECV) and unexplained error control limits (UCL $\leq 1.3 \mathrm{SECV}$ ). These limits were respected except for $\mathrm{Na}(\mathrm{UCL}=1.5 \mathrm{SECV})$ and $\mathrm{Cl}$ $(\mathrm{UCL}=1.35 \mathrm{SECV})$. The NIRS prediction performance was evaluated by several statistical criteria reported in Table 2. Generally, the coefficients of determination of prediction $\left(\mathbf{R}_{\mathbf{P}}^{2}\right)$ and the ratio of prediction to deviation $[\mathbf{R P D}=\mathrm{SD}$ of the reference data in the validation set $/$ standard errors of prediction corrected for bias, SEP(C)] are considered for evaluating the accuracy of NIRS prediction (Williams, 2001; Nie et al., 2009a). 
Table 1. Statistics for the calibration and cross-validation set used to develop near-infrared reflectance spectroscopy equations to predict timothy mineral concentrations and derived indices related to cattle metabolic disorders ${ }^{1}$

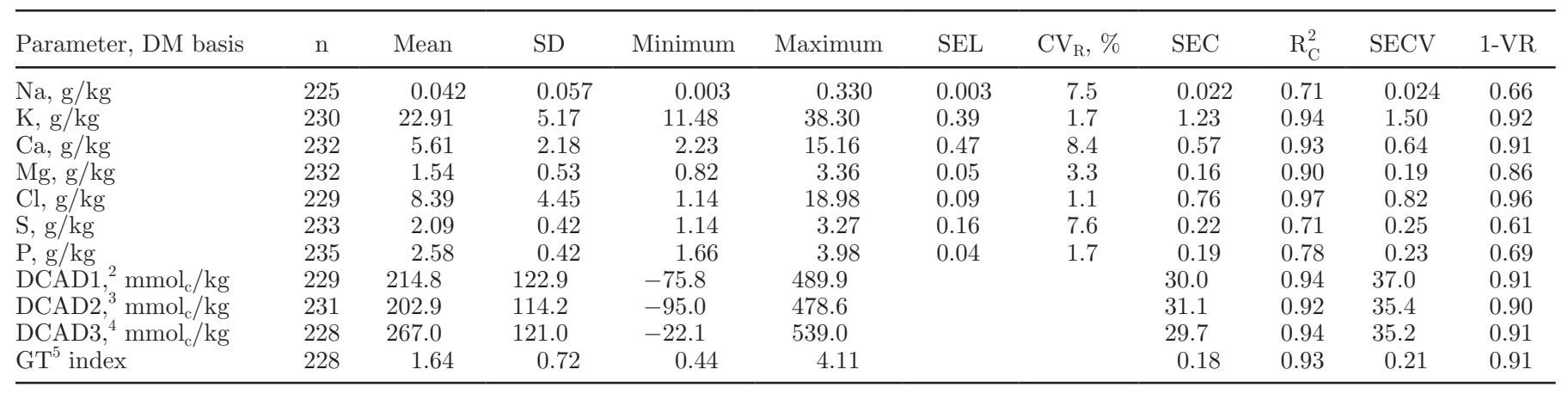

${ }^{1} \mathrm{SEL}=$ standard error of laboratory; $\mathrm{CV}_{\mathrm{R}}=$ coefficient of variation for reference methods $=(\mathrm{SEL} / \mathrm{mean}) \times 100 ;$ SEC $=$ standard error of calibration; $\mathrm{R}_{\mathrm{C}}^{2}=$ coefficient of determination of calibration; $\mathrm{SECV}=$ standard error of cross-validation; and 1-VR $=$ coefficient of determination for the cross-validation.

${ }^{2} \mathrm{DCAD} 1=(\mathrm{Na}+\mathrm{K})-(\mathrm{Cl}+\mathrm{S})\left(\right.$ Ender et al., 1971). $\mathrm{mmol}_{\mathrm{c}}=$ millimoles of charge.

${ }^{3} \mathrm{DCAD} 2=(\mathrm{Na}+\mathrm{K}+0.15 \mathrm{Ca}+0.15 \mathrm{Mg})-(\mathrm{Cl}+0.6 \mathrm{~S}+0.5 \mathrm{P})(\mathrm{NRC}, 2001)$.

${ }^{4} \mathrm{DCAD} 3=(\mathrm{Na}+\mathrm{K})-(\mathrm{Cl}+0.6 \mathrm{~S})($ Goff et al., 2004).

${ }^{5} \mathrm{GT}=$ grass tetany $=\mathrm{K} /(\mathrm{Ca}+\mathrm{Mg})(\mathrm{Kemp}$ and 't Hart, 1957).

The $\operatorname{SEP}(\mathrm{C})$ is calculated using the following formula (Naes et al., 2002):

$$
\operatorname{SEP}(C)=\sqrt{\frac{1}{n-1} \sum\left(x_{i}-y_{i}-\text { bias }\right)^{2}},
$$

where $\mathrm{n}$ is the total number of samples in the validation set, $x_{i}-y_{i}$ is the difference between results obtained by the reference method $\left(\mathrm{x}_{\mathrm{i}}\right)$ and NIRS prediction $\left(\mathrm{y}_{\mathrm{i}}\right)$ for sample $\mathrm{i}$, and the bias is calculated as follows:

$$
\operatorname{Bias}=\frac{1}{\mathrm{n}} \sum\left(\mathrm{x}_{\mathrm{i}}-\mathrm{y}_{\mathrm{i}}\right)
$$

The SECV is calculated in the same way as $\operatorname{SEP}(\mathrm{C})$ but is based on data from cross-validation. High $\mathrm{R}_{\mathrm{P}}^{2}$ and $\mathrm{RPD}$ and low SEP $(\mathrm{C})$ indicate good NIRS performance; a prediction with an $\mathrm{R}_{\mathrm{P}}^{2}>0.90$ and RPD $>3.0$ is usually classified as successful. The slope of the regression between predicted and measured values of each constituent for the validation set is also considered. As suggested by Williams (2001), a deviation of less than 0.05 from the slope value of 1.0 indicates successful NIRS equations.

Because low concentrations and a narrow range are generally observed for mineral concentrations, which could render $\mathrm{R}^{2}$ values misleading (Clark et al., 1989;

Table 2. Statistics for the validation set $(n=868)$ used to verify the performance of the near-infrared reflectance spectroscopy prediction of timothy mineral concentrations and derived indices related to cattle metabolic disorders ${ }^{1}$

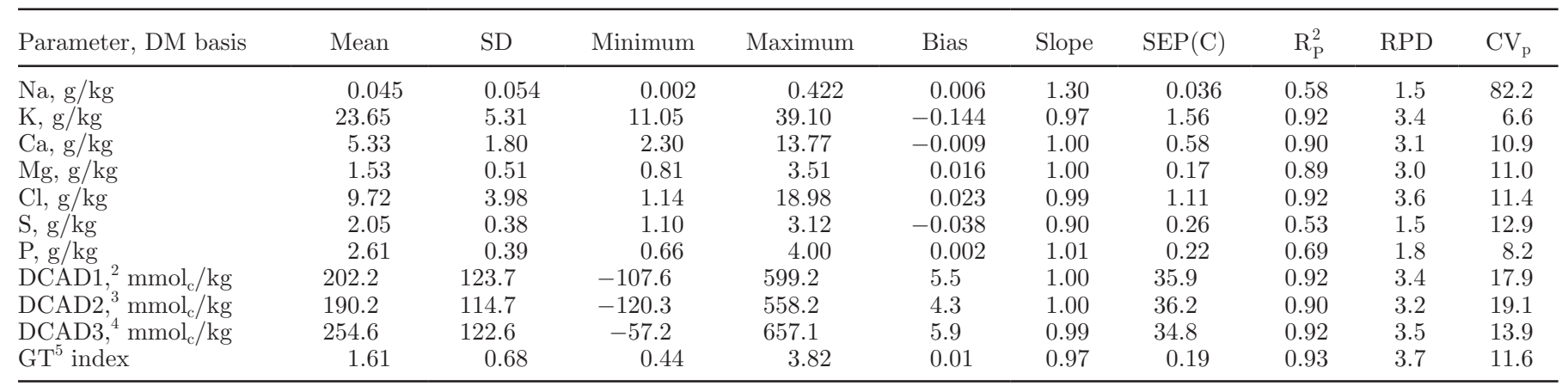

${ }^{1} \mathrm{SEP}(\mathrm{C})=$ standard error of prediction corrected for bias; $\mathrm{R}_{\mathrm{P}}^{2}=$ coefficient of determination of prediction; $\mathrm{RPD}=$ ratio of prediction to deviation $=\mathrm{SD}$ of validation set $/ \mathrm{SEP}(\mathrm{C})$; and $\mathrm{CV}_{\mathrm{P}}=$ coefficient of variation of prediction $=[\mathrm{SEP}(\mathrm{C}) / \mathrm{mean}] \times 100$.

${ }^{2} \mathrm{DCAD} 1=(\mathrm{Na}+\mathrm{K})-(\mathrm{Cl}+\mathrm{S})\left(\right.$ Ender et al., 1971) $\mathrm{mmol}_{\mathrm{c}}=$ millimoles of charge.

${ }^{3} \mathrm{DCAD} 2=(\mathrm{Na}+\mathrm{K}+0.15 \mathrm{Ca}+0.15 \mathrm{Mg})-(\mathrm{Cl}+0.6 \mathrm{~S}+0.5 \mathrm{P})(\mathrm{NRC}, 2001)$.

${ }^{4} \mathrm{DCAD} 3=(\mathrm{Na}+\mathrm{K})-(\mathrm{Cl}+0.6 \mathrm{~S})$ (Goff et al., 2004).

${ }^{5} \mathrm{GT}=$ grass tetany $=\mathrm{K} /(\mathrm{Ca}+\mathrm{Mg})(\mathrm{Kemp}$ and 't Hart, 1957). 
Murray and Cowe, 2004; Nie et al., 2009b), some authors suggest evaluating the NIRS prediction of minerals by using the coefficient of variation rather than $\mathrm{R}^{2}$. As proposed by Clark et al. (1989), the coefficient of variation of prediction $\left\{\mathbf{C V}_{\mathbf{P}}=[\mathrm{SEP}(\mathrm{C}) /\right.$ mean $\left.] \times 100\right\}$ between chemically analyzed and NIRS-predicted values is considered a useful tool in evaluating NIRS performance across minerals. Clark et al. (1987, 1989) reported useful NIRS mineral equations with coefficients of variation ranging from 11 to $28 \%$ across 3 forage data sets, and Halgerson et al. (2004) accurately predicted several minerals by NIRS in alfalfa with coefficients of variation $\leq 20 \%$ and $1-\mathrm{VR} \geq 0.60$. In the present study, the NIRS prediction performance was considered successful when $\mathrm{RPD} \geq 3, \mathrm{CV}_{\mathrm{P}} \leq 20 \%$, and $\mathrm{R}_{\mathrm{P}}^{2}$ $\geq 0.60$ for minerals, and when $\mathrm{RPD} \geq 3, \mathrm{CV}_{\mathrm{P}} \leq 20 \%$, and $\mathrm{R}_{\mathrm{P}}^{2} \geq 0.90$ for DCAD and the GT index.

\section{RESULTS AND DISCUSSION}

\section{Sample Statistics of Timothy Mineral Concentrations, the DCAD, and the GT Index}

Concentrations of different minerals in timothy varied greatly in both the calibration and validation sets, with respective mean values of 0.042 and $0.045 \mathrm{~g} / \mathrm{kg}$ of DM for $\mathrm{Na}$ to values of 22.91 and $23.65 \mathrm{~g} / \mathrm{kg}$ of DM for $\mathrm{K}$ (Tables 1 and 2). The range of concentrations was also the widest for K (26.82 and $28.05 \mathrm{~g} / \mathrm{kg}$ of DM) and the narrowest for $\mathrm{Na}(0.327$ and $0.420 \mathrm{~g} / \mathrm{kg}$ of DM; Tables 1 and 2). The range of $\mathrm{Ca}$ and $\mathrm{Cl}$ concentrations was relatively high (10 to $20 \mathrm{~g} / \mathrm{kg}$ of DM), whereas those of $\mathrm{Mg}, \mathrm{S}$, and $\mathrm{P}$ were less (2 to $4 \mathrm{~g} / \mathrm{kg}$ of $\mathrm{DM}$ ) (Tables 1 and 2). Accurate chemical analyses were conducted for all minerals, as shown by the low SEL (0.003 to 0.47 $\mathrm{g} / \mathrm{kg}$ of $\mathrm{DM}$ ) and $\mathrm{CV}_{\mathrm{R}}$ values (1.1 to $8.4 \%$ ) in Table 1 , which were close to the values reported by Halgerson et al. (2004).

Among the 3 DCAD, DCAD3 showed the highest mean value of $267.0 \mathrm{mmol}_{\mathrm{c}} / \mathrm{kg}$ of $\mathrm{DM}$ in the calibration set (Table 1); however, the mean values of all 3 were lower than the acceptable maximum for forage (Goff and Horst, 2003; Pelletier et al., 2008). The mean values of all 3 DCAD were approximately $12 \mathrm{mmol}_{\mathrm{c}} /$ $\mathrm{kg}$ of DM lower in the validation (Table 2) than in the calibration set (Table 1) but the ranges of values were all extended to varying degrees in the validation set, possibly because of a larger number of samples. The sample statistics of the GT index were similar between the calibration and validation sets, and their mean values of 1.64 and 1.61 were much lower than the acceptable maximum value of 2.2 (Jefferson et al., 2001) for rations (Tables 1 and 2).

\section{NIRS Calibration and Validation for Mineral Concentrations}

All selected NIRS predictions of mineral concentrations used to calculate the DCAD and the GT index were cross-validated with $1-\mathrm{VR}>0.60$ (Table 1 ). The best prediction was observed for $\mathrm{Cl}$ concentration, with 1-VR of 0.96 and SECV of $0.82 \mathrm{~g} / \mathrm{kg}$ of DM, and it was followed by predictions for $\mathrm{K}, \mathrm{Ca}$, and $\mathrm{Mg}$, with slightly lower 1 -VR values of $0.92,0.91$, and 0.86 , respectively. The NIRS predictive accuracy for $\mathrm{Na}, \mathrm{S}$, and $\mathrm{P}$ was relatively low, with $1-\mathrm{VR}$ of $0.66,0.61$, and 0.69 and SECV of $0.024,0.25$, and $0.23 \mathrm{~g} / \mathrm{kg}$ of DM, respectively (Table 1).

Based on the criteria of $\mathrm{CV}_{\mathrm{P}}<20 \%$ and $\mathrm{R}_{\mathrm{P}}^{2}>0.60$ (Clark et al., 1987, 1989; Halgerson et al., 2004), the NIRS predictions for $\mathrm{K}, \mathrm{Ca}, \mathrm{Mg}, \mathrm{Cl}$, and $\mathrm{P}$ concentrations were successful, with $\mathrm{CV}_{\mathrm{P}}$ ranging from 6.6 to $11.4 \%$, and $\mathrm{R}_{\mathrm{P}}^{2}$ from 0.69 to 0.92 , whereas those of $\mathrm{S}$ and $\mathrm{Na}$ were unsuccessful, with low $\mathrm{R}_{\mathrm{P}}^{2}$ of 0.53 and 0.58 and a much higher $\mathrm{CV}_{\mathrm{P}}$ of $82.2 \%$ for $\mathrm{Na}$ (Table 2). The statistic of RPD was calculated as a secondary criterion for the prediction of mineral concentrations (Table 2). All successful equations classified by the criteria of $\mathrm{CV}_{\mathrm{P}}$ and $\mathrm{R}_{\mathrm{P}}^{2}$ had $\mathrm{RPD}$ values higher than 3.0 except for $\mathrm{P}$, with an RPD of 1.8 (Table 2). Meanwhile, the unsuccessful equations for $\mathrm{Na}$ and $\mathrm{S}$ both had a low RPD of 1.5 (Table 2). The NIRS predictions of $\mathrm{K}, \mathrm{Ca}, \mathrm{Mg}, \mathrm{Cl}$, and $\mathrm{P}$ concentrations, which were classified as successful based on the criteria of $C_{\mathrm{P}}$ and $\mathrm{R}_{\mathrm{P}}^{2}$, all showed deviations of less than 0.05 from the slope value of 1.0 (Williams, 2001), with the slope values ranging from 0.97 to 1.01 (Table 2 ) in the validation sample set. The $\mathrm{Na}$ and $\mathrm{S}$ concentrations were predicted unsuccessfully, with slope values of 1.30 and 0.90 (Table 2), respectively; these values were not within the acceptable range (Williams, 2001).

The predictions of $\mathrm{P}$ and $\mathrm{S}$ were diversely classified as successful and unsuccessful according to their respective $\mathrm{R}_{\mathrm{P}}^{2}$ values of 0.69 and 0.53 . Other performance criteria for the prediction of those 2 elements, however, were close to each other, as shown by $\mathrm{CV}_{\mathrm{P}}$ of 8.2 and $12.9 \mathrm{~g} / \mathrm{kg}$ of DM and RPD of 1.8 and 1.5 for P and S, respectively (Table 2). We suggest that the successful prediction of $\mathrm{P}$ should be used with caution because the $\mathrm{R}_{\mathrm{P}}^{2}$ of 0.69 is close to the lower limit of a successful equation (0.60). On the other hand, the unsuccessful prediction of S could possibly be useful as a broad first approximation for selecting samples for more accurate analyses.

As explained by Clark et al. (1987) and Vazquez de Aldana et al. (1995), the successful prediction of 
mineral concentrations relies on their association with organic and hydrated inorganic molecules. Potassium, $\mathrm{Ca}$, and $\mathrm{Mg}$ were found to be predictable by spectral peaks of their corresponding organic acid salts (Clark et al., 1989); the wavelength used for detecting $\mathrm{Mg}$ was also similar to the peaks from the chlorophyll spectrum. Other factors that influence the accuracy of NIRS equations are the average concentration and the range for each constituent (Murray and Cowe, 2004; Nie et al., 2008). The successful predictions of $\mathrm{K}, \mathrm{Ca}$, and $\mathrm{Cl}$ in the present study were mainly explained by their higher concentrations and ranges. For example, our prediction of $\mathrm{Cl}$ concentration was better than that reported by Halgerson et al. (2004) for oven-dried alfalfa stems (n $=58 ; \mathrm{SECV}=0.69 \mathrm{~g} / \mathrm{kg} ; 1-\mathrm{VR}=0.84)$; this can be explained by higher concentrations (mean $=8.39 \mathrm{~g} /$ $\mathrm{kg}$ of $\mathrm{DM}$ ) and a greater variation in $\mathrm{Cl}$ concentrations $(\mathrm{SD}=4.45 \mathrm{~g} / \mathrm{kg}$ of $\mathrm{DM})$ in the present study (Table 1) compared with those $($ mean $=3.85 \mathrm{~g} / \mathrm{kg}$ of DM; SD = $1.71 \mathrm{~g} / \mathrm{kg}$ of DM) reported by Halgerson et al. (2004). Our higher concentrations and greater variation in $\mathrm{Cl}$ concentrations were partly caused by the application of different amounts of $\mathrm{Cl}$ fertilizers, including $\mathrm{CaCl}_{2}$ and $\mathrm{NH}_{4} \mathrm{Cl}$.

The concentrations and range of values of $\mathrm{Mg}$ were relatively low compared with $\mathrm{K}, \mathrm{Ca}$, and $\mathrm{Cl}$, but prediction of $\mathrm{Mg}$ was more successful than that of $\mathrm{P}$ and $\mathrm{S}$, which had similar concentrations and ranges of values (Tables 1 and 2). This result could possibly be attributed to its better detectability in the near-infrared spectral region.

Previous analyses suggest that $\mathrm{P}$ and $\mathrm{S}$ exist in forms detectable by NIRS in some forages (Saiga et al., 1989; Cozzolino and Moron, 2004). Both P and S in plants exist in multiple valences and in different organic forms, such as phytate, phospholipids, and nucleic acids for $\mathrm{P}$, and the proportion of total $\mathrm{P}$ and $\mathrm{S}$ in different forms varies seasonally or among species and genera. This attribute may lead to unstable NIRS calibrations and inconsistent prediction results. Prediction of $\mathrm{P}$ in our study, however, was comparable with that reported by Clark et al. (1987) in 100 crested wheatgrass samples $\left(\mathrm{SEP}=0.20 \mathrm{~g} / \mathrm{kg}, \mathrm{R}^{2}=0.84\right)$, by Halgerson et al. (2004) in oven-dried alfalfa leaves (SECV $=0.20 \mathrm{~g} / \mathrm{kg}$, $1-\mathrm{VR}=0.74)$ and stems $(\mathrm{SECV}=0.22 \mathrm{~g} / \mathrm{kg}, 1-\mathrm{VR}=$ 0.63 ), and by Vazquez de Aldana et al. (1995) in 75 samples of natural grasslands $\left(\mathrm{SEP}=0.22, \mathrm{R}_{\mathrm{p}}^{2}=0.73\right)$. Prediction of $\mathrm{S}$ failed in our study and variable results were reported by Clark et al. (1989) in crested wheatgrass $\left(\mathrm{SEP}=0.16 \mathrm{~g} / \mathrm{kg}, \mathrm{R}^{2}=0.61\right)$, by Halgerson et al. (2004) in oven-dried alfalfa leaves $(\mathrm{SECV}=0.43 \mathrm{~g} / \mathrm{kg}$, $1-\mathrm{VR}=0.12)$ and stems $(\mathrm{SECV}=0.10 \mathrm{~g} / \mathrm{kg}, 1-\mathrm{VR}=$ 0.74), and by Cozzolino and Moron (2004) in legumes
$\left(\mathrm{SEP}=5.5 \mathrm{~g} / \mathrm{kg}\right.$ and $\left.\mathrm{R}_{\mathrm{P}}^{2}=0.70\right)$. In our study, the prediction performance of $\mathrm{P}$ and $\mathrm{S}$ was restricted by their low concentrations and ranges of values. However, because $\mathrm{P}$ mean concentrations and range values $(2.58$ and $2.32 \mathrm{~g} / \mathrm{kg}$ of DM in the calibration set, and 2.61 and $3.34 \mathrm{~g} / \mathrm{kg}$ of DM in the validation set, respectively) were slightly higher than those of S $(2.09$ and $2.13 \mathrm{~g} / \mathrm{kg}$ of DM in the calibration set, and 2.05 and $2.02 \mathrm{~g} / \mathrm{kg}$ of $\mathrm{DM}$ in the validation set, respectively), we obtained a better prediction performance for $\mathrm{P}$, with $\mathrm{R}_{\mathrm{P}}^{2}$ of 0.69 , $\mathrm{CV}_{\mathrm{P}}$ of $8.2 \%$, and RPD of 1.8 , which was classified successful, whereas $\mathrm{S}$ was predicted with $\mathrm{R}_{\mathrm{P}}^{2}$ of 0.53 , $\mathrm{CV}_{\mathrm{P}}$ of $12.9 \%$, and RPD of 1.5 (Table 2).

The unsuccessful prediction of $\mathrm{Na}$ concentration in timothy was mainly attributed to its low concentration, with an average value of $0.042 \mathrm{~g} / \mathrm{kg}$ of DM (Table 1), which is well below the lowest recommended limit of NIRS analysis $(1 \mathrm{~g} / \mathrm{kg})$, and to its narrow range of 0.002 to $0.422 \mathrm{~g} / \mathrm{kg}$ of DM in all timothy samples. The excellent precision of $\mathrm{Na}$ determinations, as indicated by an SEL of $0.003 \mathrm{~g} / \mathrm{kg}$ of $\mathrm{DM}$ and a $\mathrm{CV}_{\mathrm{R}}$ of $7.5 \%$ (Table 1), was not sufficient to compensate for the low values and narrow range. Even with greater concentrations of $\mathrm{Na}(2.3 \mathrm{~g} / \mathrm{kg}$ of $\mathrm{DM})$ and $\mathrm{S}(30 \mathrm{~g} / \mathrm{kg}$ of DM), and wider ranges of concentrations of $\mathrm{Na}(0.2$ to $6.8 \mathrm{~g} /$ $\mathrm{kg}$ of DM) and $\mathrm{S}$ (20 to $72 \mathrm{~g} / \mathrm{kg}$ of DM) than in our study, Cozzolino and Moron (2004) reported NIRS predictions of $\mathrm{Na}\left(\mathrm{SEP}=1.2 \mathrm{~g} / \mathrm{kg}\right.$ of $\left.\mathrm{DM} ; \mathrm{R}_{\mathrm{P}}^{2}=0.61\right)$ and $\mathrm{S}\left(\mathrm{SEP}=5.5 \mathrm{~g} / \mathrm{kg}\right.$ of $\left.\mathrm{DM} ; \mathrm{R}_{\mathrm{P}}^{2}=0.70\right)$ in legumes that were not much better than in our study.

\section{NIRS Calibration and Validation of DCAD and the GT Index}

Calibration and cross-validation showed that NIRS predictions for all the DCAD and the GT indices were qualified, with $1-\mathrm{VR} \geq 0.90$, SECV of 35.2 to 37.0 $\mathrm{mmol}_{\mathrm{c}} / \mathrm{kg}$ of DM for the DCAD, and 0.21 for the GT index (Table 1). Based on the validation set, NIRS predictions were successful for DCAD1, DCAD2, and DCAD3, with $\mathrm{R}_{\mathrm{P}}^{2}$ of $0.92,0.90$, and 0.92 , and $\mathrm{RPD}$ values of $3.4,3.2$, and 3.5 , respectively (Table 2 ). The $\mathrm{CV}_{\mathrm{P}}$ values of $17.9 \%$ for DCAD1, $19.1 \%$ for DCAD2, and $13.9 \%$ for DCAD3 (Table 2) were all lower than the value of $20 \%$ suggested as the maximum for successful predictions of mineral concentrations. Based on $\mathrm{R}_{\mathrm{P}}^{2}$, $\mathrm{RPD}$, and $\mathrm{CV}_{\mathrm{P}}$, DCAD3 was predicted with the best accuracy, followed by DCAD1 and then by DCAD2. The slope values, ranging from 0.99 to 1.00 (Table 2), also indicate that all 3 DCAD were predicted with good accuracy (Williams, 2001). 
The predictions of all 3 DCAD were successful even though $\mathrm{Na}$ and $\mathrm{S}$ concentrations, which are used in the calculation of all $3 \mathrm{DCAD}$, were both predicted unsuccessfully by NIRS. This result could be explained by the minor influence of these 2 minerals on DCAD values; $\mathrm{Na}$ and $\mathrm{S}$ were among the lowest concentrations as compared with other minerals, especially $\mathrm{K}$ and $\mathrm{Cl}$. The better NIRS prediction of DCAD3 than DCAD1 can be explained by the influence of unsuccessful prediction of S concentration, which was weakened by adding a coefficient of 0.6 for $\mathrm{S}$ in the DCAD3 calculation. The slightly lower prediction accuracy for DCAD2 than for the 2 other DCAD predictions can be attributed, in part, to the fact that the calculation of DCAD2 involves more minerals $(\mathrm{Ca}, \mathrm{Mg}$, and $\mathrm{P}$ ); these minerals would introduce their own laboratory errors into the calculated values of DCAD2.

The best NIRS prediction for the GT index had a 1 -VR value of 0.91 and an SECV of 0.21 (Table 1), and the statistics for the validation set $\left(\mathrm{R}_{\mathrm{P}}^{2}=0.93, \mathrm{RPD}=\right.$ $3.7, \mathrm{CV}_{\mathrm{P}}=11.6 \%$, and slope $=0.97$; Table 2) confirmed that this equation was successful. Good NIRS prediction of the GT index reflects the fact that concentrations of $\mathrm{K}, \mathrm{Ca}$, and $\mathrm{Mg}$ were successfully predicted (Tables 1 and 2).

This study focused on a single grass species, and we have demonstrated the possibility of predicting the DCAD and the GT index of timothy. Most forage grown in eastern Canada, however, is based on several species, including both legumes and grasses, within the same field. Applying these NIRS equations to other plant species or mixtures of different species should be done with great caution. To develop more robust and practical NIRS predictions for rapid analyses of minerals, DCAD, and GT indices, further research is required in which the NIRS prediction of samples of multiple forage species would be studied.

\section{CONCLUSIONS}

Near-infrared reflectance spectroscopy successfully predicted concentrations of $\mathrm{K}, \mathrm{Ca}, \mathrm{Mg}, \mathrm{Cl}$, and $\mathrm{P}$, as well as the DCAD and the GT index in timothy forage samples; the prediction of $\mathrm{P}$, however, was associated with an $\mathrm{R}_{\mathrm{P}}^{2}$ close to the lower limit of a successful equation. The NIRS prediction of $\mathrm{Na}$ and $\mathrm{S}$ failed mainly because of their low concentrations and narrow ranges.

\section{ACKNOWLEDGMENTS}

The authors acknowledge the technical assistance of Mario Laterrière and Danielle Mongrain (Agriculture and Agri-Food Canada, Soils and Crops Research and Development Centre, Québec, Canada). We also acknowledge the assistance of Christina McRae, from Editworks (Wolfville, Nova Scotia, Canada), for the structural editing of this manuscript. This study was funded by the "Action concertée Agriculture et Agroalimentaire Canada (Sherbrooke, Québec, Canada)-Fonds québécois de la recherché sur la nature et les technologies (Québec, Canada)-Ministère de l'agriculture, des pêcheries et de l'alimentation du Québec (Québec, Canada)-NOVALAIT Inc. (Québec, Canada) (2002-2005)" and the Ministry of Education of China-Agriculture and Agri-Food Canada, Québec $\mathrm{PhD}$ research program.

\section{REFERENCES}

Barnes, R. J., M. S. Dhanoa, and S. J. Lister. 1989. Standard normal variate transformation and de-trending of near infrared diffuse reflectance spectra. Appl. Spectrosc. 43:772-777.

Bélanger, G., R. Michaud, P. G. Jefferson, G. F. Tremblay, and A. Bregard. 2001. Improving the nutritive value of timothy through management and breeding. Can. J. Plant Sci. 81:577-585.

Charbonneau, E., D. Pellerin, and G. R. Oetzel. 2006. Impact of lowering dietary cation-anion difference in nonlactating dairy cows: A meta-analysis. J. Dairy Sci. 89:537-548.

Clark, D. H., E. E. Cary, and H. F. Mayland. 1989. Analysis of trace elements in forages by near infrared reflectance spectroscopy. Agron. J. 81:91-95.

Clark, D. H., H. F. Mayland, and R. C. Lamb. 1987. Mineral analysis of forages with near infrared reflectance spectroscopy. Agron. J. 79:485-490.

Cozzolino, D., and A. Moron. 2004. Exploring the use of near infrared reflectance spectroscopy (NIRS) to predict trace minerals in legumes. Anim. Feed Sci. Technol. 111:161-173.

DeGaris, P. J., and I. J. Lean. 2008. Milk fever in dairy cows: A review of pathophysiology and control principles. Vet. J. 176:58-69.

Ender, F., I. W. Dishington, and A. Helgebostad. 1971. Calcium balance studies in dairy cows under experimental induction and prevention of hypocalcaemic paresis puerperalis. Z. Tierphysiol. Tierernahr. Futtermittelkd. 28:233-256.

Goff, J. P., and R. L. Horst. 2003. Role of acid-base physiology on the pathogenesis of parturient hypocalcaemia (milk fever)-The DCAD theory in principal and practice. Acta Vet. Scand. Suppl. 97:51-56.

Goff, J. P., R. Ruiz, and R. L. Horst. 2004. Relative acidifying activity of anionic salts commonly used to prevent milk fever. J. Dairy Sci. $87: 1245-1255$.

Halgerson, J. L., C. C. Sheaffer, N. P. Martin, P. R. Peterson, and S. J. Weston. 2004. Near-infrared reflectance spectroscopy prediction of leaf and mineral concentrations in alfalfa. Agron. J. 96:344-351.

Horst, R. L., J. P. Goff, T. A. Reinhardt, and D. R. Buxton. 1997. Strategies for preventing milk fever in dairy cattle. J. Dairy Sci. 80:1269-1280

Isaac, R. A., and W. C. Johnson. 1976. Determination of total nitrogen in plant tissue, using a block digestor. J. Assoc. Off. Anal. Chem. 59:98-100.

Jefferson, P. G., H. F. Mayland, K. H. Asay, and J. D. Berdahl. 2001. Variation in mineral concentration and grass tetany potential among Russian wildrye accessions. Crop Sci. 41:543-548.

Kemp, A., and M. L. 't Hart. 1957. Grass tetany in grazing milking cows. Neth. J. Agric. Sci. 5:4-17.

Lean, I. J., P. J. DeGaris, D. M. McNeil, and E. Block. 2006. Hypocalcemia in dairy cows: Meta-analysis and dietary cation anion difference theory revisited. J. Dairy Sci. 89:669-684.

Liu, L. 1998. Determination of chloride in plant tissue. Pages 111-113 in Handbook of Reference Methods for Plant Analysis. Y. P. Kalra, ed. CRC Press, Boca Raton, FL. 
Miller, R. O. 1998. High-temperature oxidation: Dry ashing. Pages 53-56 in Handbook of Reference Methods for Plant Analysis. Y. P. Kalra, ed. CRC Press, Boca Raton, FL.

Mills, H., and J. B. Jones Jr. 1996. Plant Analysis Handbook II: A Practical Sampling, Preparation, Analysis, and Interpretation Guide. MicroMacro Publishing Inc., Athens, GA

Murray, I., and I. Cowe. 2004. Sample preparation. Pages 75-112 in Near-Infrared Spectroscopy in Agriculture. C. A. Roberts, J. Workman, and J. B. Reeves, ed. Am. Soc. Agron., Crop Sci. Soc. Am., Soil Sci. Soc. Am., Madison, WI.

Naes, T., T. Isaksson, T. Fearn, and T. Davies. 2002. A User-Friendly Guide to Multivariate Calibration and Classification. NIR Publications, Chichester, UK.

NRC. 2001. Nutrient Requirements of Dairy Cattle. 7th rev. ed. National Academic Press, Washington, DC.

Nie, Z., J. Han, T. Liu, and X. Liu. 2008. Application of support vector machine method in prediction of alfalfa protein fractions by near infrared reflectance spectroscopy. J. Dairy Sci. 91:2361-2369.

Nie, Z., G. F. Tremblay, G. Bélanger, R. Berthiaume, Y. Castonguay, A. Bertrand, R. Michaud, G. Allard, and J. Han. 2009a. Nearinfrared reflectance spectroscopy prediction of neutral detergentsoluble carbohydrates in timothy and alfalfa. J. Dairy Sci. 92:1702-1711

Nie, Z., G. F. Tremblay, G. Bélanger, R. Berthiaume, Y. Castonguay, A. Bertrand, R. Michaud, G. Allard, and J. Han. 2009b. Carbohydrates in alfalfa-timothy mixtures predicted with near infrared reflectance spectroscopy equations developed for single species. Can. J. Anim. Sci. 89:279-283.

Pelletier, S., G. Belanger, G. F. Tremblay, M. H. Chantigny, and G. Allard. 2008. Dietary cation anion difference and tetany index of timothy forage fertilized with liquid swine manure. Agron. J. 100:213-220.

Pelletier, S., G. Belanger, G. F. Tremblay, P. Seguin, R. Drapeau, and G. Allard. 2007. Dietary cation-anion difference of Timothy (Phleum pratense L.) as influenced by application of chloride and nitrogen fertilizer. Grass Forage Sci. 62:66-77.

Redshaw, E. S., G. W. Mathison, L. P. Milligan, and R. D. Weisenburger. 1986. Near infrared reflectance spectroscopy for predicting forage composition and voluntary consumption and digestibility in cattle and sheep. Can. J. Anim. Sci. 66:103-115.

Saiga, S., T. Sasaki, K. Nonaka, K. Takahashi, M. Watanabe, and K. Watanabe. 1989. Prediction of mineral concentrations of orchardgrass (Dactylis glomerata L.) with near infrared reflectance spectroscopy. J. Jpn. Soc. Grassl. Sci. 35:228-233.

Shenk, J. S., and M. O. Westerhaus. 1991. Population structuring of near infrared spectra and modified partial least squares regression. Crop Sci. 31:1548-1555.

Shenk, J. S., and M. O. Westerhaus. 1994. The application of near infrared reflectance spectroscopy (NIRS) to forage analysis. Pages 406-499 in Forage Quality Evaluation and Utilization. G. C. Fahey, ed. Am. Soc. Agron., Crop Sci. Soc. Am., Soil Sci. Soc. Am., Madison, WI.

Stoltz, M. A. 1990. Provisional assessment of quality components in lucerne (Medicago sativa) and white clover (Trifolium repens) using a near-infrared reflectance spectrophotometer. S. Afr. J. Plant Soil 7:105-112.

Thomas, E. D., C. J. Sniffen, R. D. Allshouse, C. S. Ballard, S. Miyoshi, and C. J. Majewski. 1998. Potassium fertilization of forage grasses for dry cows. Research Report 98-5. William H. Miner Agricultural Research Institute, Chazy, NY.

Tremblay, G. F., H. Brassard, G. Belanger, P. Seguin, R. Drapeau, A. Bregard, R. Michaud, and G. Allard. 2006. Dietary cation anion difference of five cool-season grasses. Agron. J. 98:339-348.

Urbano-Cuadrado, M., M. D. Luque de Castro, P. M. Pérez-Juan J. García-Olmo, and M. A. Gómez-Nieto. 2004. Near infrared reflectance spectroscopy and multivariate analysis in enology: Determination or screening of fifteen parameters in different types of wines. Anal. Chim. Acta 527:81-88.

Vazquez de Aldana, B. R., B. Garcia, A. Criado, Garcia, Ciudad, and M. E. Perez Corona. 1995. Estimation of mineral content in natural grasslands by near infrared reflectance spectroscopy. Commun. Soil Sci. Plant Anal. 26:1383-1396.

Williams, P. C. 2001. Implementation of near-infrared spectroscopy Pages 145-169 in Near-Infrared Technology in the Agricultural and Food Industries. 2nd ed. P. C. Williams and K. Norris, ed. Am. Assoc. Cereal Chem., St. Paul, MN. 